\title{
THE LEVEL OF JOB SATISFACTION IN PUBLIC SECTOR: A SURVEY STUDY IN THE PROVINCE OF AĞRI, EASTERN ANATOLIA, TURKEY
}

\author{
Orhan Çınar ${ }^{1}$, Fatih Karcioğlu ${ }^{2}$ \\ ${ }^{1}$ Ataturk University, Turkey,orhanar@gmail.com \\ ${ }^{2}$ Ataturk University, Turkey, fkarci@gmail.com \\ cross $^{\text {ref }}$ http://dx.doi.org/10.5755/j01.em.17.2.2203
}

\begin{abstract}
This study was carried out in 19 governmental offices located in the province of Ağrı, Eastern Anatolia, aiming to find out the job satisfaction level of public sector workers. Using descriptive survey design, the sample of the study was 267 public sector workers. To collect the data a scale including 20 items and two factors with five-point Likert was used. It was generated by three Turkish researchers in 1998 and based on Herzberg's two factor theory. As a result of the study it was found out that the level of workers' job satisfaction was middle also the same result remained valid for the other two factors. Another result was that there had been some differences according to workers' characteristics. It was observed that the higher the position or academic qualification, the higher the job satisfaction level. The strong side of the study was that it was considerably comprehensive because it was held in all offices of the province and the number of responses was quiet adequate. On the other hand such a study was firstly done in public sector in the province. Thus it can be said that this study was worthwhile for the governance of the province.

Keywords: Work, job satisfaction, public sector, Turkey.

JEL Classification: D23, M10, M12.
\end{abstract}

\section{Introduction}

Work is an important aspect of human life. Some consider work as a source of prestige and social recognition while some evaluate work as meaningful because it provides the excitement of creativity and the opportunity to give something to them. But for most, the main purpose of work is to make money for living. However, this does not indicate that money is the only reward in a job; friendship, the change to exercise power and feeling useful are also important (Ghosh and Ghorpade, 1991). Workforce was adopted as only one of the inputs of the production system in the initial stages of the industrial revolution. It was the Hawthorne Studies carried out by Elton Mayo from 1924 to 1932 that revealed the shift in the perception about employees by organizations. These studies resulted that workers are not motivated solely by money and that workers behaviour is linked to their attitudes. The Hawthorne Studies began the human relations approach to management, whereby the needs and motivation of workers become the primary focus of managers (Kulkarni and Chiniwar, 2009).

As a large part of one's life is spent in work place, it can be said that working life should be pleasant for someone. Unhappiness with work life influences both the work life and the rest sections of human life. Beside this fact, organizations are social systems where human resources are the most important factors for effectiveness and efficiency. Organizations need effective managers and workers to achieve their objectives. Organizations cannot succeed without their human resource efforts and commitment. Therefore, organizations need to understand factors affecting their human resource performance.

The purpose of this study is to find out the level of job satisfaction of public sector workers and to make comparisons according to their demographic characteristics. Using descriptive survey design, the sample of the study is 267 public sector workers working in the public offices located in the province of Ağr1, Eastern Anatolia, Turkey. Following sections consist of theoretical background, research methodology, analysis results and conclusion.

\section{Theoretical Background}

The quality of work life experienced by workers in organizations has been an area of great interest for practitioners and researchers. The concept of job satisfaction has been one of significant concepts related to the quality of work life. As job satisfaction has been assumed to be a factor leading organizational commitment, overall organizational success and development, growth, effectiveness and efficiency of the organization and low worker's intention to leave the organization (Ahmet et al., 2010), it has been and will be a much studied one in management and organization literature. Ghosh and Ghorpade (1991) denote that despite the number of research on the job satisfaction concept, theories related to this concept are not highly developed and furthermore most are generated from motivation theories (Table 1). 
Table 1. Major approaches to theories of job satisfaction (Ghosh and Ghorpade, 1991:398)

\begin{tabular}{|l|c|l|}
\hline \multicolumn{1}{|c|}{ Name / Description } & $\begin{array}{c}\text { Related Theory of } \\
\text { Work Motivation }\end{array}$ & \multicolumn{1}{|c|}{ Basic Tenets } \\
\hline $\begin{array}{l}\text { Two factor of Motivation / } \\
\text { Hygiene (Herzberg, Mausner and } \\
\text { Snyderman, 1959) }\end{array}$ & Need Theory & $\begin{array}{l}\text { Job satisfaction and job dissatisfaction are } \\
\text { separate issues; satisfaction comes only from } \\
\text { factors intrinsic to work itself. }\end{array}$ \\
\hline $\begin{array}{l}\text { Social comparison or Facet } \\
\text { Satisfaction (Lawler, 1973) }\end{array}$ & Cognitive Theories & $\begin{array}{l}\text { Satisfaction depends on perception of job inputs, } \\
\text { job characteristics, and job outputs relative to } \\
\text { other people. }\end{array}$ \\
\hline Value Theory (Locke, 1975) & $\begin{array}{l}\text { Satisfaction comes from being able to achieve } \\
\text { things one values by means of job relative to } \\
\text { other people. }\end{array}$ \\
\hline Opponent Process (Landy, 1978) & None Directly Related & $\begin{array}{l}\text { Satisfaction varies over time forces always acting } \\
\text { to reduce it. }\end{array}$ \\
\hline $\begin{array}{l}\text { Subtractive or Need Discrepancy } \\
\text { (Porter, 1961) }\end{array}$ & Need Theory & $\begin{array}{l}\text { Satisfaction results from low discrepancy between } \\
\text { what person needs and what job gives. }\end{array}$ \\
\hline $\begin{array}{l}\text { Instrumentality (Porter and } \\
\text { Lawler, 1968) }\end{array}$ & Expectancy Theory & $\begin{array}{l}\text { Satisfaction depends on match between expected } \\
\text { and obtained rewards. }\end{array}$ \\
\hline
\end{tabular}

It is acknowledged in the literature that the concept of job satisfaction and the assessment of job satisfaction started first in 1911 with the research of Frank Taylor. According to Taylor rewards like the earnings of the practiced job, promotion, incentive payments, appreciation, and opportunities for progress could achieve job satisfaction (Şirin, 2009). On the other hand Hopock initially brought this term into usage in 1935 and defined job satisfaction as "any combination of psychological and environmental circumstances that cause a person to say truthfully: I am satisfied with my job" (Ghosh and Ghorpade, 1991).

Mulinge and Mueller (1998) state that job satisfaction studies have mainly utilized one or a combination of three broad theoretical approaches: the social psychological (exchange) approach, the neoclassical economic approach, and a more sociological approach. However, the social psychologists' exchange perspective seems the dominating one in the literature. Nurullah (2010) explains that more than 5,000 studies of job satisfaction have been published around the world examining the impact of different psycho-socio-economic factors on job satisfaction. These have examined the role of self-esteem, gender, education, income and happiness.

Poggy (2010) suggests that interest in well-being and in job satisfaction comes from some observations. These are:

Studying this topic may contribute utility theories,

As this topic is seen as indicator of work quality, it is considered as a key element for supporting workers and productivity,

$\square \quad$ As it is one of the determinants of a good life, thus studying job satisfaction may contribute a theory of social good.

$\square$ If the policies focus on the determinants of job satisfaction it could be possible to improve satisfaction and, therefore, employment and productivity.

Astrauskaite et al. (2011) state that although job satisfaction has been broadly researched, still there are several problems and they listed them as: misunderstandings because of many definitions, complexity in measurement because of plentiful instruments, and inconvenience between measurement instruments and the sample researched.

Ahmet et al. (2010) propose that the discussion on job satisfaction started with the publication of Herzberg's book named "The Motivation to Work" in 1959. In this book engineers and accountants were asked to narrate a story about the event when they went exceptionally bad or exceptionally good. According to those situations Herzberg divided work dimensions in two elements: Motivators and Hygiene factors. Motivators and satisfying factors were achievement, recognition, work itself, responsibility, advancement, and growth. Hygiene factors were administration of the company and its policy, supervisory behaviour, relationship with superiors, working environment, salary, relationship with co-workers, relationships with subordinates, status, personal life, and safety measures. Herzberg implemented that the causes of job satisfaction lay in the intrinsic factors and the causes of dissatisfaction lay in extrinsic factors. 
Definition and dimensions of job satisfaction: Job satisfaction is typically defined as the pleasurable or positive emotional condition coming from the assessment of one's job or job experience (Locke, 1976). McShane and Steen (2009) characterize job satisfaction as "a collection of attitudes about different aspects of the job and work context". Jafar et al. (2010) listed five major aspects of job satisfaction: Job itself, supervisor, colleagues, salary and promotions. They state that during the year 1950 to 1960, many studies concerned about presenting an obvious relation between job satisfaction and performance but according to all studies in the field of job satisfaction and performance, they found that there is no firm correlation between them whereas, there is a positive relation in between.

Locke (1976) reveals the dimensions used in the assessment of job satisfaction as the job itself, payment, promotion, working conditions, benefits of the work, fellow workers, personal values, employeeemployer relationship. In addition to these, Şirin (2009) suggests more factors affecting job satisfaction as follows: A feeling of success, relations with the management, relations with employees, job safety, more responsibility, being recognized, high salary, promotion opportunity, clarity of roles, participation in decisions, freedom, good coordinated work, lack of continuity, relocation, performance, life satisfaction, trade unions, and perceived work stress.

According to Luthans (1998) there are three important features of job satisfaction:

- Job satisfaction is an emotional response to a job situation so it cannot be seen, it can only be deduced.

- Job satisfaction is often determined by how well outcome meets or exceeds expectations. For example, if members feel that they are working harder than others but are receiving fewer rewards, they will probably have negative attitudes towards the work, the boss and or co-workers. On the other hand, if they feel there is justice then they are likely to have positive attitudes towards the job.

- Job satisfaction indicates several related attitudes which are most important characteristics of a job about which people have effective response. These are: the work itself, pay, promotion opportunities, supervision and co-workers.

The importance of job satisfaction: Green (2010) posits that job satisfaction has been used as a measure of job quality by many writers. Thus, when the quality of work is treated, the job satisfaction concept is taken as an indicator for an assessment for employment policies.

Job satisfaction is so important to organizations because it reduces employee turnover, laziness, absenteeism, tardiness, and health setbacks due to stress and increases organizational commitment (Rusbult, et al. 1988; Tet and Meyer, 1993; Moser, 1997; Allen, 2006; Chimanikire, 2007). Workers who are satisfied at their workplaces show positive attitudes in their homes and make a psychologically healthy society.

On the other hand, dissatisfied employees are more likely to quit their jobs or be absent than satisfied employees. Chiboiwa et al. (2011) express that there is a positive relationship between labour turnover and job dissatisfaction in existing literature. Lack of job satisfaction is an indicator of quitting a job. Sometimes workers may quit from public to the private sector and vice versa. At the other times the movement is from one profession to another one and people tend to migrate to better jobs (Tella, et al., 2007). According to Al$\mathrm{Zu}$ 'bi (2010), job satisfaction is critical to retaining and attracting well-qualified workers, and more satisfied employees have more innovative activities in continuous quality improvement. It is obvious that organisations loose productivity, social capital and suffer customer defection when a productive worker quits.

\section{Methodology}

Using descriptive survey design, the sample of the study is 267 public sector workers working in the public offices located in the province of Ağrı, Eastern Anatolia, Turkey. The study held in 19 governmental offices of the province. Table 2 shows the names of the offices and the distribution of the sample. 
Table 2. Public institutions

\begin{tabular}{|l|c|c|}
\hline & N & \% \\
\hline National Education Administration & 36 & 13.5 \\
\hline Revenue Office & 30 & 11.2 \\
\hline Special Provincial Administration & 24 & 9.0 \\
\hline Agriculture Administration & 24 & 9.0 \\
\hline Social Security Administration & 23 & 8.6 \\
\hline Land Registry and Cadastre Office & 23 & 8.6 \\
\hline Governor's Staff & 18 & 6.7 \\
\hline Health Administration & 13 & 4.9 \\
\hline Public Works and Housing Office & 11 & 4.1 \\
\hline Youth and Sport Administration & 11 & 4.1 \\
\hline Environment and Forest Administration & 10 & 3.7 \\
\hline Social Services Administration & 10 & 3.7 \\
\hline Road Chief Office & 8 & 3.0 \\
\hline Labor Placement Office & 7 & 2.6 \\
\hline Demography and Citizenship Office & 7 & 2.6 \\
\hline Science, Industry and Technology Office & 5 & 1.9 \\
\hline Culture and Tourism Administration & 4 & 1.5 \\
\hline Civil Defense Office & 3 & 1.1 \\
\hline Total & $\mathbf{2 6 7}$ & $\mathbf{1 0 0 . 0}$ \\
\hline
\end{tabular}

Objective of the Study: The purpose of this study is to find out the level of job satisfaction of public sector workers and to make comparisons according to their demographic characteristics. The following research questions were developed to guide the study:

$\square$ What is the level of job satisfaction among public sector workers?

$\square$ Is there any difference between the levels of job satisfaction when comparing to the public workers' demographic characteristics accordingly?

Instrument: The questionnaire used to collect the data was specifically designed and divided into two sections. The first section collected information such as age, gender, seniority, position, academic qualification, and so on. The second section contained a scale including 20 items with five-point Likert is used. The scale was generated by Kuzgun et al. (1998) in 1998 and based on Herzberg's two factor theory. They revealed that the aim of the scale was to measure the level of happiness of workers to be a member of their current job. The scale consists of two factors: the former one is called as conformity to properties and the latter one is called as self-development tendency. First factor consists of questions to determine how much the worker and job fit to each other. In this point of view Robbins et al. (1998) emphasise the importance of ability-job fit, rather than pure assessment of ability, as being an important determinant of job performance and satisfaction. The second factor consists of questions related to the self-development willingness of the worker in her/his job. If workers want to develop themselves in their current job then it is possible to deduce that this situation indicates that there is a job satisfaction. The overall reliability coefficient of the instrument yielded an $\mathrm{r}=0.86$ while first factor yielded an $\mathrm{r}=0.83$ and second factor yielded an $\mathrm{r}=0.76$ Cronbach Alpha.

To evaluate the scores a range table was established shown in Table 3. As the scale consists of 20 items with five-point Likert from 1 to 5, one can get the highest score as 100 and the lowest score as 20 over the scale wholly. We divided this range (20 to 100) into 3 parts as low, middle and high. The same process was also applied for the other two factors.

Table 3. Job satisfaction score evaluation

\begin{tabular}{|c|c|c|c|}
\hline $\begin{array}{c}\text { Job satisfaction (20 } \\
\text { items) }\end{array}$ & $\begin{array}{c}\text { Conformity to } \\
\text { properties (12 items) }\end{array}$ & $\begin{array}{c}\text { Self-development } \\
\text { tendency (8 items) }\end{array}$ & Evaluation \\
\hline $20-46$ & $12-27$ & $8-18$ & Low \\
\hline $47-73$ & $28-44$ & $19-29$ & Middle \\
\hline $74-100$ & $45-60$ & $30-40$ & High \\
\hline
\end{tabular}


Procedure: The instrument was administered to public sector workers after the approval of the governor of the province.

Data Analysis: Descriptive statistics such as frequency, percentage, mean and standard deviation and for classification t-test and one-way Anova were applied to analyze the collected data. Only observed statistically significant differences were tabulated.

Results: The results of the analysis on the study are below. Demographic characteristics of participants are shown in Table 4.

Table 4. Demographic characteristics of participants

\begin{tabular}{|c|c|c|}
\hline & Number & Percentage $(\%)$ \\
\hline \multicolumn{3}{|l|}{ Gender } \\
\hline Female & 54 & 20.0 \\
\hline Male & 213 & 79.8 \\
\hline Total & 267 & 100.0 \\
\hline \multicolumn{3}{|l|}{ Position } \\
\hline Manager & 18 & 6.7 \\
\hline Vice-manager & 41 & 15.4 \\
\hline Officer & 208 & 77.9 \\
\hline Total & 267 & 100.0 \\
\hline \multicolumn{3}{|l|}{ Academic Qualification } \\
\hline Primary school & 7 & 2.6 \\
\hline Secondary school & 93 & 34.8 \\
\hline Vocational high school & 47 & 17.6 \\
\hline Faculty & 120 & 44.9 \\
\hline Total & 267 & 100.0 \\
\hline \multicolumn{3}{|l|}{ Seniority } \\
\hline To 1 year & 35 & 13.1 \\
\hline $1-5$ years & 51 & 19. \\
\hline $6-10$ years & 31 & 11.6 \\
\hline $11-15$ years & 35 & 13.1 \\
\hline More than 15 years & 115 & 43.1 \\
\hline Total & 267 & 100.0 \\
\hline \multicolumn{3}{|l|}{ Age } \\
\hline To 25 years & 25 & 9.4 \\
\hline $25-35$ years & 99 & 37.1 \\
\hline $36-45$ years & 81 & 30.3 \\
\hline More than 45 years & 62 & 23.2 \\
\hline Total & 267 & 100.0 \\
\hline
\end{tabular}

Research Question 1: What is the level of job satisfaction among public sector workers?

Table 5. Job satisfaction scores

\begin{tabular}{|l|c|c|c|}
\hline \multicolumn{1}{|c|}{$\mathbf{N = 2 6 7}$} & St. D. & Mean Score & $\begin{array}{c}\text { Evaluation } \\
\text { (according to } \\
\text { Table 3) }\end{array}$ \\
\hline Job Satisfaction & 14.71 & 68.45 & Middle \\
\hline $1^{\text {st }}$ factor: Conformity to properties & 10.26 & 38.51 & Middle \\
\hline $2^{\text {nd }}$ factor: Self-development tendency & 6.37 & 29.94 & Middle \\
\hline
\end{tabular}

Table 5 shows the mean scores of workers' job satisfaction and the other two factors. According to findings job satisfaction level is middle. The same result is also obtained for job satisfaction factors.

Reaserch Question 2: Is there any difference between the levels of job satisfaction and of the other two factors when comparing to the public workers' demographic characteristics accordingly?

$\mathrm{T}$ test was used while comparing to two groups (gender), one-way Anova was used while comparing more than two groups (position, academic qualification, seniority and age of participants), and Scheffe test was performed to discover which groups differ from each other. 
Table 6. Comparisons according to position

\begin{tabular}{|c|c|c|c|c|c|c|}
\hline & \multicolumn{3}{|c|}{ Mean scores according to position } & \multirow[b]{2}{*}{$\begin{array}{l}\text { Difference } \\
\text { between }\end{array}$} & \multirow[b]{2}{*}{$\mathbf{F}$} & \multirow[b]{2}{*}{$\mathbf{p}$} \\
\hline & Manager & $\begin{array}{c}\text { Vice- } \\
\text { manager }\end{array}$ & Officer & & & \\
\hline Job satisfaction & 77.56 & 73.05 & 66.75 & $\begin{array}{l}\text { Manager X } \\
\text { Officer }\end{array}$ & 7.154 & 0.001 \\
\hline Conformity to properties & 44.39 & 40.49 & 37.61 & $\begin{array}{l}\text { Manager, Vice- } \\
\text { manager } \\
\text { X Officer }\end{array}$ & 4.646 & 0.010 \\
\hline Self-development tendency & 33.17 & 32.56 & 29.15 & $\begin{array}{l}\text { Manager, Vice- } \\
\text { manager } \\
\text { X Officer }\end{array}$ & 7.758 & 0.001 \\
\hline
\end{tabular}

After applying one-way Anova according to workers' position, statistically significant differences were observed for job satisfaction $[\mathrm{F}=7.154, \mathrm{p}=0.001<0.05]$, conformity to properties $[\mathrm{F}=4.646$, $\mathrm{p}=0.010<0.05]$, and self-development tendency $[\mathrm{F}=7.7757, \mathrm{p}=0.001<0.05]$. As it is seen from the Table 6, managers' job satisfaction score (77.56) is higher than that of officers' (66.75). In addition to this, mean scores of managers and vice-managers are higher than that of officers for conformity to properties and selfdevelopment tendency. According to these findings it can be said that the higher the position the higher the job satisfaction level.

Table 7. Comparisons according to academic qualification

\begin{tabular}{|c|c|c|c|c|}
\hline Self-development tendency & $\begin{array}{l}\text { Mean } \\
\text { score }\end{array}$ & Difference between & $\mathbf{F}$ & $\mathbf{p}$ \\
\hline Primary School & 25.00 & \multirow{4}{*}{$\begin{array}{l}\text { Primary School } \\
\text { X } \\
\text { Vocational High School, Faculty } \\
\text { AND } \\
\text { Secondary School } \\
\text { X } \\
\text { Faculty }\end{array}$} & \multirow{4}{*}{2.807} & \multirow{4}{*}{0.040} \\
\hline Secondary School & 29.06 & & & \\
\hline Vocational High School & 30.23 & & & \\
\hline Faculty & 30.80 & & & \\
\hline
\end{tabular}

Table 7 shows the observed statistically significant differences when comparing mean scores according to academic qualification. Differences were observed only for self-development tendency factor $[\mathrm{F}=2.807, \mathrm{p}=0.040<0.05]$. There are differences between mean scores of workers having primary school qualification and workers having vocational high school qualification. The same result obtained between primary school and faculty, and between secondary school and faculty. This means that academically qualified workers have higher mean scores. In brief this result indicates that the higher the academic qualification the higher mean score for self-development tendency.

\section{Conclusion}

As a result of the study it is found out that the level of workers' job satisfaction was middle also the same result remained valid for the other job satisfaction factors: Conformity to properties and the selfdevelopment tendency. Another result was that there had been some differences according to workers' characteristics. It was observed that the higher the position or academic qualification, the higher the job satisfaction level.

The strong side of the study is that it is considerably comprehensive because it was held in all offices of the province and the number of responses was quiet adequate. On the other hand such a study was firstly done in public sector in the province. Thus it can be said that this study is worthwhile for the governance of the province.

If we mention about the limitations of the study, the data collected in one province of Turkey so one cannot generalize the findings to other provinces of the country. Beside this we measured only one concept (job satisfaction) in this study. Future researchers may study more concepts and look for the relations between them in the public sector of the province. 


\section{References}

1. Ahmed, I., et al. (2010). "Effects of motivational factors on employees' job satisfaction a case study of University of the Punjab, Pakistan", International Journal of Business and Management, 5(3):70-80.

2. Allen, D. G. (2006). "Do organizational socialization tactics influence newcomer embeddedness and turnover?", Journal of Management, 32:237-256.

3. Al-Zu'bi, H. A. (2010). "A study of relationship between organizational justice and job satisfaction", International Journal of Business and Management, 5(12):102-109.

4. Astrauskaite, M., Vaitkevičius, R. and Perminas, A. (2011). "Job satisfaction survey: a confirmatory factor analysis based on secondary school teachers' sample", International Journal of Business and Management, 6(5):41-50.

5. Chiboiwa, M. W., Chipunza, C. and Samuel, M. O. (2011). "Evaluation of job satisfaction and organisational citizenship behaviour: case study of selected organisations in Zimbabwe", African Journal of Business Management, 5(7):2910-2918.

6. Chimanikire, P. (2007). "Factors affecting job satisfaction among academic professionals in tertiary institutions in Zimbabwe", African Journal of Business Management, 1(6):166-175.

7. Ghosh, P. K. and Ghorpade, M. B. (1991). Industrial and Organizational Psychology, Himalaya Publishing House, Bombay.

8. Green, F. (2010). "Well-being, job satisfaction and labour mobility”, Labour Economics, 17:897-903

9. Jafar, R., et al. (2010). "The study of job satisfaction among Bandar Abbas Islamic Azad University staff", Procedia Social and Behavioral Sciences 5:258-261.

10. Kulkarni, P. M. and Chiniwar, S. G. (2009). "Employee motivation and work performance - a study of small-scale sector in the city of Belgaum, Karnataka State, India", International Conference on Technology and Business Management, March 29-April 1, 701-706.

11. Kuzgun,Y., Sevim, S. A. ve Hamamcı, Z. (1998), Mesleki Doyum Ölçeği, Türk Psikolojik Danışma ve Rehberlik Dergisi, 11:14-18.

12. Locke, E. A. (1976). “The nature and causes of job satisfaction”, In M. D. Dunnette (Ed.), Handbook of Industrial and Organizational Psychology (pp.1297-1349). Chicago: Rand McNally, 1976.

13. Luthans, F. (1998). Organisational Behaviour, Boston: Irwin McGraw-Hill.

14. McShane, S. L. and Steen, S. (2009). Canadian Organizational Behaviour (7th ed.). Toronto: McGraw-Hill.

15. Moser, K. (1997). “Commitment in organizations", Psychologies, 41(4): 160-170.

16. Mulinge, M. and Mueller, C. W. (1998). "Employee Job Satisfaction in Developing Countries: The Case of Kenya", World Development, 26(12):2181-2199.

17. Nurullah, A. S. (2010). "Predictors of job satisfaction among emerging adults in Alberta, Canada", International Journal of Business and Management, 5(3):3-15.

18. Poggi, A. (2010). "Job satisfaction, working conditions and aspirations", Journal of Economic Psychology 31:936949.

19. Robbins, S. P., Millett, B., Cacioppe, R. and Waters-Marsh, T. (1998). Organisational Behaviour: Leading and Managing in Australia and New Zealand, Prentice Hall, Sydney.

20. Rusbult, C. E., et al. (1998). "Impact of exchange variables on exit, voice, loyalty, and neglect: an integrative model of responses to declining job satisfaction", Academy of Management Journal, 31(3): 599-627.

21. Şirin, A. F. (2009). "Analysis of relationship between job satisfaction and attitude", Journal of Theory and Practice in Education, 5(1), 85-104.

22. Tella, A., Ayeni, C. O. and Popoola, S. O. (2007). "Work motivation, job satisfaction, and organisational commitment of library personnel in academic and research libraries in Oyo State, Nigeria", Library Philosophy and Practice, April, 1-16.

23. Tett, R. P. and Meyer, J. P. (1993). "Job satisfaction, organizational commitment, turnover intention, and turnover: path analyses based on meta-analytic findings", Personnel Psychology, 46(2): 259-293. 